\title{
Status of Tef (Eragrostis tef) Diseases in Ethiopia
}

\author{
Ashenafi Gemechu*, Kebebew Assefa, Yazachew Genet and Tsion Fikre \\ Ethiopian Institute of Agricultural Research, Ethiopia
}

Submission: July 27, 2018, Published: August 24, 2018

"Corresponding author: Ashenafi Gemechu, EIAR, Debre Zeit Agricultural Research Center, P.0. Box 32, Debre Zeit, Ethiopia, Tel: 0926897678; Email: gemechuashenafi@gmail.com

\begin{abstract}
Tef (Eragrostis tef) is the most important cereals in Ethiopia, is threatened by abiotic and biotic constraints. Among the biotic, tef leaf rust (Uromyces eragrostis) is one of the major constraints of tef production. Information on the occurrence and reaction of cultivars to tef leaf rust in Ethiopia was not well known. Therefore, the aim of this survey was to observe the performance of commercial cultivars and understand the distribution of major tef diseases in the country. The survey was made in 2016 main cropping seasons (in October) following the main roads and accessible routes in each survey district, and stops were made at every 5-10km intervals based on vehicles odometers as per tef fields presented. Five stops were made in each tef field by moving "X" fashion at each stop interval and data were collected from each. A total of 19 districts were covered during the survey. In each surveyed areas the incidence and severity of tef diseases were recorded. A total of 41 fields were observed in all assessed regions and all the observed fields were infected by tef leaf rust disease. The prevalent of tef leaf rust disease was $100 \%$ in all regions. The highest tef leaf rust disease severity of (60S) was observed in Gurage on lately planted tef varieties Quncho and Magna. For tef leaf rust disease this attack was unusual. From the assessed fields Quncho variety was the most popular (38\%) and followed by Magna which accounts about 31\% area coverage. Different severity levels were also recorded on the variety Quncho, local and Magna variety based on different agro ecologies. The current assessment indicated that the highest severity of the disease in different tef varieties and their occurrence across districts was highly variable. The disease was severe in Meskan, Sankura, Worabe and Shashemene districts with severity of 50-60S. The severity of the disease was increased because of improved agronomic practices (Row planting, late planting and cultivars) that are susceptible to disease become common and no chemical control was practiced to tef leaf rust disease so far. Currently, the disease was becoming severe and using fungicide may be an option to control this disease. The other issue is screening of germplasm to this disease and selecting those tolerant line(s) and incorporating in breeding program will also another option to control this disease in the future
\end{abstract}

Keywords: Survey; Tef leaf rust; cultivation; Fertility; Moisture scarcity

Abbreviations: SNNP: Southern Nation and Nationality of People; GPS: Geographic Positioning System; ESRI: Environmental Systems Research Institute

\section{Introduction}

Tef is endemic to Ethiopia and its major diversity is found only in that country as with several other crops, the exact date and location for the domestication of tef is unknown. However, there is no doubt that it is a very ancient crop in Ethiopia, where domestication took place before the birth of Christ. Tef is an important cereal crop in Ethiopia. The area under tef cultivation is over one million hectares of land each year. In 2016/17, it was estimated that tef made up to $24 \%$ of all the cultivated area in Ethiopia, covering about 3.02 million hectares and grown by 6.99 million farmers [1]. Tef is grown in almost all regions of the country for home consumption since it is a preferred grain, and for local market since it fetches the highest grain price compared with other cereals and is used as a cash crop by farmers. Although the crop is dominantly cultivated as sole crop, it is also grown as an intercrop or mixed crop, relay crop or in rotation with several types of crops [2,3]. The crop is grown both in belg (short rainy season) and meher (long rainy season).
The regions in Ethiopia identified as highly suitable for tef production include Gojam and Shewa, which are located in the central highlands of Ethiopia and are also the largest and major tef production areas in the country modern varieties are used as well as traditional landraces and local cultivars. There are different constraints of tef yield reduction. These are biotic and abiotic constraints. Biotic factors include diseases, insects and weeds and abiotic (lodging, poor soil fertility and moisture scarcity). Tef rust (Uromyces eragrustidis Tracy) and head smudge (Helminthosporium miyakei Nisikado) have been reported as the most important diseases on tef [4,5]. Recently other biotic factors such as loose smut, leaf blast and zonate eye spot diseases are observed on different tef varieties. The importance of such diseases might increase with change of agronomic practices (row planting) and disease surveying is so important. Therefore, the aim of this survey was for observing the performance of commercial cultivars and understanding the distribution of major tef diseases in the country. 


\section{Materials and Methods}

\section{Survey of tef diseases}

Tef diseases survey was conducted during 2016 cropping season in five major tef producing Zones of Oromia and Southern Nation and Nationality of People (SNNP) regions were assessed. A total of 41 fields were assessed in 19 districts were observed. Three to five stops were made in each Tef field along a diagonal move at each stop interval. During the survey crop growth stage was not the same. The survey was conducted during crop growth stage of grain filling, heading and maturity based on agro ecologies of the surveyed areas. Disease prevalence, incidence and severity were recorded for tef leaf rust and smut. The disease prevalence was calculated using the number of fields affected divided by the total number of fields assessed and expressed in percentage. Incidence was calculated by using the number of plants infected and expressed as percentage of the total number of plants assessed. Severity was scored visually using the modified Cobb's Scale:

\section{Where:}

$0 \%=$ immune

$100 \%=$ completely susceptible

Peterson et al. [6] but there was no immune response for the reaction between tef varieties and the tef rust disease. There were no resistant and moderately resistant responses of tef varieties across the surveyed areas. For smut disease incidence was taken. Three survey routes were done based on the most tef growing regions and suitable for the occurrence of major tef diseases. Trips were arranged based on the crop growth stage and the disease occurrence. The surveys were made following the main roads and accessible routes in each survey district, and stops were made at every 5-10 km intervals based on vehicles odometers and on the availability of tef in the farmers' field.

The tef diseases incidence and severity of each field was computed from five stops. The results of the survey were summarized by districts and varieties. The geographic coordinates (latitude and longitude), and altitude were recorded using Geographic Positioning System (GPS) unit. The latitude and longitude coordinates were used to map the distribution of the tef leaf rust and other tef diseases in the surveyed areas using the Environmental Systems Research Institute (ESRI) Arc View 3.0.

\section{Results and Discussions}

\section{Survey of Tef diseases}

Tef diseases survey was conducted in Oromia, Amhara and Southern Nation and Nationality of People (SNNP) regions have been presented in Table 1. The diseases survey covered seven zones namely West Arsi, South West Shoa, East Shoa, North Shoa, Gurage, Silte and Hadiya in twenty-nine districts. The distributions and intensities of the tef leaf rust disease were observed in all surveyed districts at variable levels of surveyed fields depending on the agro-ecologies and varieties grown.

Table 1: Geographical distribution, incidence and severity of tef leaf rust disease in 2016 main growing seasons.

\begin{tabular}{|c|c|c|c|c|c|c|c|}
\hline \multirow{2}{*}{ Zones } & \multirow{2}{*}{ Districts } & \multirow{2}{*}{ Total fields } & \multirow{2}{*}{ Infected Fields } & \multicolumn{3}{|c|}{ Tef leaf rust } & \multirow[t]{2}{*}{ Altitude } \\
\hline & & & & Prevalence & Incidence & Severity & \\
\hline \multirow{4}{*}{$\begin{array}{c}\text { South West } \\
\text { Shoa }\end{array}$} & Ilu & 2 & 2 & 100 & 90 & $10 \mathrm{~S}-20 \mathrm{MS}$ & \multirow{4}{*}{$1823-2351$} \\
\hline & Becho & 2 & 2 & 100 & 100 & $10-15 \mathrm{MS}$ & \\
\hline & Woliso & 4 & 4 & 100 & 80 & 10MS-15S & \\
\hline & Goro & 2 & 2 & 100 & 100 & 20S, 20MS & \\
\hline \multirow{6}{*}{ Gurage } & Kobena & 1 & 1 & 100 & 100 & $25 \mathrm{~S}$ & \multirow{6}{*}{$1912-2352$} \\
\hline & Gubare & 1 & 1 & 100 & 60 & $30 \mathrm{~S}$ & \\
\hline & Agena & 2 & 2 & 100 & 100 & $10 \mathrm{MS}-35 \mathrm{~S}$ & \\
\hline & Meskan & 5 & 5 & 100 & 100 & $30-60 S$ & \\
\hline & Atu & 1 & 1 & 100 & 100 & $50 \mathrm{~S}$ & \\
\hline & Sodo & 1 & 1 & 100 & 100 & $40 \mathrm{~S}$ & \\
\hline \multirow{3}{*}{ Silte } & Worabe & 6 & 6 & 100 & 80 & $30-50 \mathrm{~S}$ & \multirow{3}{*}{$1877-2231$} \\
\hline & Sankura & 3 & 3 & 100 & 100 & $30 \mathrm{~S}-50 \mathrm{~S}$ & \\
\hline & Wulbarak & 1 & 1 & 100 & 100 & $20 \mathrm{MS}$ & \\
\hline \multirow{3}{*}{ Hadiya } & Anlemo & 1 & 1 & 100 & 80 & $20 \mathrm{MS}$ & $1998-2251$ \\
\hline & Analemu & 2 & 2 & 100 & 100 & $25-40 \mathrm{~S}$ & \multirow{5}{*}{$1763-1970$} \\
\hline & Lemu & 1 & 1 & 100 & 80 & $20 \mathrm{MS}$ & \\
\hline \multirow{3}{*}{ West Arsi } & Shashemene & 2 & 2 & 100 & 100 & $20-50 \mathrm{~S}$ & \\
\hline & Wondo Genet & 2 & 2 & 100 & 80 & $30 \mathrm{~S}$ & \\
\hline & Arsi Negelle & 2 & 2 & 100 & 90 & 10-30MS & \\
\hline Total & 19 & 41 & 41 & & & & \\
\hline
\end{tabular}


Tef leaf rust was the most important disease in distribution and intensity at all the surveyed Regional states (Oromia, Amhara and SNNP). A total of sixty-six fields were observed in all assessed regions and all the observed fields were infected by tef leaf rust disease. The prevalent of tef leaf rust disease was 100\% in all regions (Table 2). The lowest severity of tef leaf rust was recorded

Table 2: Prevalence, Incidence and Severity of diseases on tef genotypes.

\begin{tabular}{|c|c|c|c|c|c|c|c|c|c|c|c|c|}
\hline \multirow[t]{2}{*}{ Diseases } & \multicolumn{3}{|c|}{ Quncho } & \multicolumn{3}{|c|}{ Magna } & \multicolumn{3}{|c|}{ Kora } & \multicolumn{3}{|c|}{ Local } \\
\hline & Prev. & Inc & Sev & Prev. & Inc. & Sev. & Prev. & Inc. & Sev. & Prev. & Inc. & Sev. \\
\hline Tef Rust & 100 & 100 & $60 \mathrm{~S}$ & 100 & 100 & $60 \mathrm{~S}$ & 100 & 80 & $30 \mathrm{MS}$ & 100 & 100 & $30 \mathrm{MS}$ \\
\hline Smut & 4 & 5 & & 4 & 0 & & 4 & 0 & & 4 & 10 & \\
\hline
\end{tabular}

The highest severity has been observed in SNNP region frequently at different zones. The highest tef leaf rust disease severity of (60S) was observed in Gurage on lately planted tef varieties Quncho and Magna. In most zones of this region the tef leaf rust has been observed in all parts of the plant above the ground parts (Stem, leaf sheath, pandicle, panicle, spikelet). For tef leaf rust disease this attack was unusual.

From the assessed fields Quncho variety was the most popular (38\%) and followed by Magna which accounts about 31\% area coverage. Different severity levels were also recorded on the variety Quncho, local and Magna variety based on different agro ecologies. The smut diseased sample was observed under microscope. The shape and size of the spores looks like the loose smut that attacks the false oats and barley. For further identification the tef seeds will be infected by the pathogen and then planted at green house.

\section{Conclusion and Recommendations}

Even though the yield loss caused by this pathogen is not clearly studied and quantified in the area in the studied crop, this study indicates the presence of multiple diseases at different growth stage of the tef. In this study, one pathogen attacking tef plant was observed across surveyed areas. Among all fungal diseases reported, tef leaf rust is the most frequently encountered diseases in surveyed areas.

Results from tef leaf rust survey in nineteen zones reveals that tef leaf rust was prevalent everywhere tef variety is grown during main season with varying degree of incidence and severity. However, the occurrence of the tef leaf rust disease was $100 \%$ in all of the surveyed area of the zones. The disease was severe in Meskan, Sankura, Worabe and Shashemene districts with severity of 50-60S. The severity of the disease was increased because of improved agronomic practices (Row planting and cultivars) that are susceptible to disease become common and no chemical control was practiced to tef leaf rust disease.

Generally, in nineteen zones where survey was conducted 38 and $31 \%$ of the fields were planted by varieties relatively in South West Shoa and West Arsi Zones. In these zones the severity ranges from 10S-15MS (Table 1). Smut has been observed in both West Arsi, (Arsi Negelle District) and Alaba Zones during the surveying season. The incidence of this disease was about $10 \%$ in the observed fields. In all assessed fields in Oromia region the tef leaf rust disease attacks only the leaves of the tef varieties. susceptible reaction of Quncho and Magna, respectively. Efforts should be made towards the integration of multiple disease control options. Varietal diversification is also another issue to minimize the effect of this disease. This study indicates that there was no the use of fungicide to control this disease. Currently, the disease was becoming severe and using fungicide may be an option to control this disease. The other issue is screening of germplasm to this disease and selecting those tolerant line(s) and incorporating in breeding program will also another option to control this disease in the future.

\section{Acknowledgement}

We would like to offer a great thanks to tef research team of Debre Zeit Agricultural Research Center for their valuable encouragement and technical support during the whole period of the study.

\section{References}

1. CSA (Central Statistical Agency) (2016) Agricultural Sample Survey. Report on Area and Production of Major Crops. Statistical Bulletin 584, Vol.1, Addis Ababa, Ethiopia.

2. Fufa H, Tesfaye B, Hailu T, Kebebew A, Tiruneh K, et al. (2001) Agronomy Research in Tef. In: Hailu Tefera, et al. (Eds.), Narrowing the Rift: Tef Research and Development, Proceedings of the International Workshop on Tef Genetics and Improvement, Addis Ababa, Ethiopia, pp: 167-176.

3. Walelign Worku (2004) Maize tef relay intercropping as affected by maize planting pattern and leaf removal in southern Ethiopia. African Crop Science Journal 12(4): 358-367.

4. Stewart RB, Dagnachew Yirgou (1967) Index of plant diseases in Ethiopia. Bull Exp Stn Coll Agric Halle Selassie Univ 30(95): 335.

5. Tareke Berehe (1981) Inheritance of lemma colour, seed colour and panicle form among four cultivars of Eragrostis tef (Zucc.) Trotter. University of Nebraska, Lincoln, USA.

6. Peterson RF, Campbell AB, Hannah AE (1948) A diagrammatic scale for estimating rust intensity on leaves and stems of cereals. Canadian Journal of Research 26: 496-500. 
CC (1) This work is licensed under Creative BY DOI: 10.19080/ARTOAJ.2018.17.556026
Your next submission with Juniper Publishers will reach you the below assets

- Quality Editorial service

- Swift Peer Review

- Reprints availability

- E-prints Service

- Manuscript Podcast for convenient understanding

- Global attainment for your research

- Manuscript accessibility in different formats

( Pdf, E-pub, Full Text, Audio)

- Unceasing customer service

Track the below URL for one-step submission https://juniperpublishers.com/online-submission.php 